\title{
A STUDY OF THE FLUCTUATIONS IN SEA-ICE EXTENT OF THE BERING AND OKHOTSK SEAS WITH PASSIVE MICROWAVE SATELLITE OBSERVATIONS
}

\author{
(Abstract) \\ by \\ D.J. Cavalieri and C.L. Parkinson \\ (Laboratory for Oceans, NASA Goddard Space Flight Center, Greenbelt, MD 20771, U.S.A.)
}

\begin{abstract}
The seasonal sea-ice cover of the combined Bering and Okhotsk Seas at the time of maximum ice extent is almost $2 \times 10^{6} \mathrm{~km}^{2}$ and exceeds that of any other seasonal sea-ice zone in the Northern Hemisphere. Although both seas are relatively shallow bodies of water overlying continental shelf regions, there are important geographical differences. The Sea of Okhotsk is almost totally enclosed, being bounded to the north and west by Siberia and Sakhalin Island, and to the east by Kamchatka Peninsula. In contrast, the Bering Sea is the third-largest semi-enclosed sea in the world, with a surface area of $2.3 \times 10^{6} \mathrm{~km}^{2}$, and is bounded to the west by Kamchatka Peninsula, to the east by the Alaskan coast, and to the south by the Aleutian Islands arc.

While the relationship between the regional oceanography and meteorology and the sea-ice covers of both the Bering Sea and Sea of Okhotsk have been studied individually, relatively little attention has been given to the occasional out-of-phase relationship between the fluctuations in the sea-ice extent of these two large seas. In this study, we present 3 day averaged sea-ice extent data obtained from the Nimbus-5 Electrically Scanning Microwave Radiometer (ESMR-5) for the four winters for which ESMR-5 data were available, 1973 through 1976, and document those periods for which there is an out-of-phase relationship in the fluctuations of the ice cover between the Bering Sea
\end{abstract}

and the Sea of Okhotsk. Further, mean sea-level pressure data are also analyzed and compared with the time series of sea-ice extent data to provide a basis for determining possible associations between the episodes of out-of-phase fluctuations and atmospheric circulation patterns.

Previous work by Campbell and others (1981) using sea-ice concentrations also derived from ESMR-5 data noted this out-of-phase relationship between the two ice packs in 1973 and 1976. The authors commented that the out-of-phase relationship is "... surprising as these are adjacent seas, and one would assume that they had similar meteorologic environments". We argue here that the out-of-phase relationship is consistent with large-scale atmospheric circulation patterns, since the two seas span a range of longitude of about $60^{\circ}$, corresponding to a half wavelength of a zonal wave-number 3 , and hence are quite susceptible to changes in the amplitude and phase of large-scale atmospheric waves.

\section{REFERENCE}

Campbell W J, Ramseier R O, Zwally H J, Gloersen P 1981 Structure and variability of Bering and Okhotsk sea-ice cover by satellite microwave imagery. In Halboury M T (ed) Energy Resources of the Pacific Region. American Association of Petroleum Geologists. Tulsa, OK: 343-354

\section{AIRBORNE UHF RADAR MEASUREMENTS OF CALDERA GEOMETRY AND VOLCANIC HISTORY, MOUNT WRANGELL, ALASKA, U.S.A. \\ (Abstract)}

by

G.K.C. Clarke and G.M. Cross

(Department of Geophysics and Astronomy, University of British Columbia, Vancouver, BC V6T 1W5, Canada)

and

C.S. Benson

(Geophysical Institute, University of Alaska, Fairbanks, AK 99701, U.S.A.)

\section{ABSTRACT}

The ice-filled caldera of Mount Wrangell, Alaska, provides an unusual opportunity to examine the interaction between a glacier and an active volcano. The caldera acts as a giant calorimeter, preserving a rough balance between snow precipitation at the glacier surface and bottom melting. In April 1982 we sounded the glacier using an airborne $840 \mathrm{MHz}$ pulsed radar (Narod B B, Clarke G K C 1983 UHF radar system for airborne surveys of ice thickness.
Canadian Journal of Earth Sciences 20(7): 1073-1086). The data were recorded on magnetic tape, then computer processed and plotted as depth, rather than time, sections.

In addition to mapping ice thickness, we detected extensive internal layers presumed to have been deposited during past eruptions of Mount Wrangell. The challenge of interpreting these internal reflectors inspired us to develop a unified interpretation model that incorporates both glaciological measurements and phenomenological equations for 